\title{
Technical Varieties of Ross Procedure: A Case Series
}

\author{
Huma Fatima1, Muneer Amanullah², Asif Hasan Siddiqui2, Abdus Salam¹ and Shirin Saeed³
}

\begin{abstract}
Replacement of aortic valve with the pulmonary autograft is carried out through the Ross procedure due to its potential for growth, durability in pediatric population, and absence of anticoagulation. This case series reports the postoperative outcome of two technical variations of Ross procedure in eight patients who underwent surgery from January 2007 to December 2016. The dominant valvular hemodynamic indication was aortic regurgitation. The techniques employed for Ross procedure included free standing root replacement in six patients and modified root replacement with autograft stabilisation using Dacron interposition graft in two patients. Right ventricular outflow tract (RVOT) conduit reconstruction was achieved by utilisation of Contegra bio prosthesis in four patients; and use of manually constructed valved conduit comprising of PTFE (polytetrafluoroethelene) membrane and bovine pericardial tube in remaining four patients. There was no mortality and no re-intervention. The technical varieties of Ross procedure offer freedom from need of anti-coagulation, mortality, and RVOT conduit failure in younger adults.
\end{abstract}

Key Words: Ross procedure, Techniques, Free standing root replacement, Autograft, Younger adults.

\section{INTRODUCTION}

Ross procedure (RP) is therapeutic for patients with a diseased aortic valve with particular benefits in pediatric population due to hemodynamic advantages, adaptation to growth, and freedom from anti-coagulation. ${ }^{1}$ In a systematic review of reports between 1967 and 2013 by Berdajs and colleagues, the overall survival was $>90 \%$ over 10 years after Ross procedure. ${ }^{2}$ In the same study, freedom from overall re-intervention over 10 years was superior to $93 \%$ in comparison to $10 \%$ re-operation rate with mechanical prosthesis and $30 \%$ with bioprosthesis. ${ }^{2}$

First described by Donald Ross in 1967, ${ }^{3}$ RP has undergone technical evolution to prevent the late complications associated with it. Initially, the modality used was subcoronary technique which includes implantation of free dissected leaflets of pulmonary root in a sub-coronary position in the aortic root. ${ }^{3}$ However, because of technical complexity as well as failure due to structural valve deterioration, the procedure did not gain wide acceptance. ${ }^{4}$

In late 1980s, invention of free-standing root replacement modality, which includes aortic root replacement with a pulmonary root autograft, brought a wider approval of the Ross procedure due to its relative less demanding nature. 4 Owing to the higher re-operation rate due to late aortic root dilation and rising aortic regurgitation even

1 Medical Student, The Aga Khan University Hospital, Karachi, Pakistan

2 Department of Surgery, The Aga Khan University Hospital, Karachi, Pakistan

3 Medical Student, The Ziauddin University, Karachi, Pakistan

Correspondence: Dr. Muneer Amanullah, Department of

Surgery, The Aga Khan University Hospital, Karachi, Pakistan

E-mail: muneer.amanullah18@gmail.com

Received: February 14, 2018; Accepted: September 07, 2018 with this technique, 5 a number of techniques have evolved to support the autograft. These manipulations mainly are composed of stabilisation of autograft annulus and autograftsinotubular junction with Teflon patch or pericardium to avoid dilatation of these sites. 6 Other modifications that have been proposed in literature are wrapping the entire autograft externally with a tubular polyester graft to prevent aneurysmal enlargement of neo-aortic root or by the use of Dacron interposition graft. 7

The technique of insertion of pulmonary autograft in Ross procedure plays a key role in determining the need of autograft re-operation which is the principal limitation of this procedure. These techniques aim to stabilise the aortic root geometry and avoid pulmonary autograft dilatation that leads to subsequent development of aortic regurgitation (AR), a common means of late RP failure. Limited literature available regarding RP in local population merits the need of comprehensive review to assess operative and postoperative course in this population.

The objective of this report was to describe the outcome of two variations of Ross procedure.

\section{METHODOLOGY}

This case series was conducted at a tertiary care hospital, after receiving approval from Ethics Review Committee. The patient population reported includes all eight patients who underwent the Ross procedure during the 10 years duration between January 2007 and December 2016. All preoperative, surgical, and post-operative data were obtained from medical records of the patients.

All procedures were carried out by a single surgeon. Intraoperative transesophageal two-dimensional and color-flow Doppler echocardiography was performed to assess pulmonary valve competence and diameters 
of pulmonary root's annulus and sinuses. After heparanization, standard cardiopulmonary bypass was used. Blood cardioplegia $\left(4^{\circ} \mathrm{C}\right)$ was given initially through aortic root and then via coronary ostia for myocardial protection. Transverse aortotomy was performed in all patients. In all cases, pulmonary autograft was used for aortic root replacements with coronary reimplantation. Continuous running suture technique was employed in all the patients. There were minimal differences between the aortic annulus and the autograft. Six patients received free standing total root replacement while two patients with mixed aortic stenosis and aortic regurgitation had Dacron tube (Vascutek, Terumo Cardiovascular Systems Inc, Ann Arbor, MI) interposed between the autograft and the ascending aorta to stabilise the autograft and prevent aneurysmal enlargement of neo-aortic root. Contegra bio prosthesis conduit was used in four patients and manually constructed composite valved conduit including a combination of PTFE (polytetrafluoroethelene) membrane and bovine pericardium in other four patients. Aortic cross clamp was removed after reconstruction of RVOT. At the end of procedure, competence of pulmonary autograft and RVOT conduit was confirmed by transesophageal echocardiography.

\section{RESULTS}

Demographic characteristics and dominant hemodynamic conditions are shown in Table I. The median age of patients was 14 years. Three patients had received previous cardiac surgeries. Two patients had undergone ventricular septal defect (VSD) closure in the past. One patient underwent balloon aortic valvuloplasty. Another patient underwent aortic valve repair previously in childhood. Four patients had bicuspid aortic valves.

Table I: Demographics of the series.

\begin{tabular}{|c|c|c|c|c|c|c|}
\hline Patient No. & Age (years) & Gender & $\begin{array}{l}\text { Dominant } \\
\text { hemodynamic } \\
\text { condition }\end{array}$ & $\begin{array}{l}\text { Previous } \\
\text { intervention }\end{array}$ & $\begin{array}{l}\text { NYHA } \\
\text { Pathology }\end{array}$ & Valve \\
\hline 1 & 14 & Female & AS/AR & None & Class 3 & Endocarditis \\
\hline 2 & 11 & Male & AS/AR & $\begin{array}{l}\text { Balloon aortic } \\
\text { valvuloplasty }\end{array}$ & Class 1 & $\begin{array}{l}\text { Bicuspid } \\
\text { aortic valve }\end{array}$ \\
\hline 3 & 27 & Female & AS/AR & None & Class 1 & $\begin{array}{l}\text { Bicuspid } \\
\text { aortic valve }\end{array}$ \\
\hline 4 & 14 & Male & $\mathrm{AR}$ & VSD closure & Class 2 & None \\
\hline 5 & 11 & Female & AR & $\begin{array}{l}\text { Aortic valve } \\
\text { repair VSD closure }\end{array}$ & Class 1 & None \\
\hline 6 & 13 & Male & $\mathrm{AR}$ & None & Class 1 & $\begin{array}{l}\text { Bicuspid } \\
\text { aortic valve }\end{array}$ \\
\hline 7 & 19 & Male & AS & None & Class 1 & $\begin{array}{l}\text { Bicuspid } \\
\text { aortic valve }\end{array}$ \\
\hline 8 & 16 & Male & AR & None & Class 2 & None \\
\hline
\end{tabular}

$A S=$ Aortic stenosis, $A R=$ Aortic regurgitation, $V S D=$ Ventricular septal defect.

Table II: Intraoperative data and postoperative course.

\begin{tabular}{|c|c|c|c|c|c|c|c|c|c|c|}
\hline Patient No. & CPB time (min) & $\begin{array}{l}\text { Aortic cross } \\
\text { clamp time (min) }\end{array}$ & $\begin{array}{l}\text { Operative } \\
\text { technique }\end{array}$ & $\begin{array}{l}\text { RVOT } \\
\text { conduit used }\end{array}$ & $\begin{array}{l}\text { RVOT } \\
\text { conduct sizes }\end{array}$ & $\begin{array}{l}\text { Concomitant } \\
\text { procedures }\end{array}$ & $\begin{array}{l}\text { ICU stay } \\
\text { (days) }\end{array}$ & $\begin{array}{l}\text { Acute } \\
\text { complications }\end{array}$ & $\begin{array}{l}\text { Neo-aorta } \\
\text { deterioration }\end{array}$ & $\begin{array}{l}\text { Follow-up } \\
\text { duration }\end{array}$ \\
\hline 1 & 195 & 170 & $\begin{array}{l}\text { Modified total root } \\
\text { replacement with } \\
\text { Dacron interposition }\end{array}$ & $\begin{array}{l}\text { Contegra Bior } \\
\text { osthesis }\end{array}$ & 22 & PDA ligation & 2 & None & Mild AR & 3 \\
\hline 2 & 240 & 180 & $\begin{array}{l}\text { Modified total root } \\
\text { replacement with } \\
\text { Dacron interposition }\end{array}$ & $\begin{array}{l}\text { PTFE membrance } \\
\text { and bovine pericardial } \\
\text { tueb graft }\end{array}$ & 20 & None & 3 & Perioperative & No & 12 \\
\hline 3 & 205 & 165 & $\begin{array}{l}\text { Free standing } \\
\text { root replacement }\end{array}$ & $\begin{array}{l}\text { PTFEE membrane } \\
\text { and bovine pericardial } \\
\text { tube graft }\end{array}$ & 22 & None & 2 & None & Trace AR & 3 \\
\hline 4 & 180 & 160 & $\begin{array}{l}\text { Free standing } \\
\text { root replacement }\end{array}$ & Contegrabioprosthesis & 20 & None & 1 & None & Mild AR & 1 \\
\hline 5 & 216 & 170 & $\begin{array}{l}\text { Free standing root } \\
\text { replacement }\end{array}$ & Contegrabioprosthesis & 22 & None & 1 & None & No & 72 \\
\hline 6 & 200 & 155 & $\begin{array}{l}\text { Free standing root } \\
\text { replacement }\end{array}$ & Contegrabioprosthesis & 22 & None & 1 & $\begin{array}{l}\text { Generalised } \\
\text { tonic clonic } \\
\text { seizures }\end{array}$ & Severe AR & 24 \\
\hline 7 & 180 & 150 & $\begin{array}{l}\text { Free standing root } \\
\text { replacement }\end{array}$ & $\begin{array}{l}\text { PTFE membrance } \\
\text { and bovine pericardial } \\
\text { tube graft }\end{array}$ & 20 & None & 2 & Seizures & Trace AR & 36 \\
\hline 8 & 190 & 145 & $\begin{array}{l}\text { Free standing root } \\
\text { replacement }\end{array}$ & $\begin{array}{l}\text { PTFE membrance } \\
\text { and bovine pericardial } \\
\text { tube graft }\end{array}$ & 22 & None & 2 & Sepsis & Trace AR & 3 \\
\hline
\end{tabular}

$\overline{C P B}=$ Cardiopulmonary bypass, $\quad R V O T=$ Right ventricular outflow tract,$\quad A R=$ Aortic regurgitation. 
Details of intraoperative and postoperative course are listed in Table II. Median CBP and cross-clamp time were $198 \mathrm{~min}$ and $162 \mathrm{~min}$, respectively. One patient received PDA ligation concomitantly. No mortality occurred in this set of patients. Complications included two post-operative seizures, and perioperative bleeding in another. Median ICU stay in this series was 2 days.

In this series, none of the patients underwent autograft replacement in the follow-up duration. Bacterial valve endocarditis or valve related thromboembolism was also not seen.

Echocardiography showed severe neo-aortic valve regurgitation in one patient on last follow-up. Three patients demonstrated trace AR and another two had mild AR on last follow-up visit. Trace pulmonary regurgitation was seen in two patients while mild RVOT obstruction with peak pulmonary gradients of $20 \mathrm{~mm}$ of mercury and $22 \mathrm{~mm}$ of mercury noticed in two patients. They were all asymptomatic with normal right ventricular function. None of the patients underwent re-operation for RVOT conduit failure in the follow-up duration.

\section{DISCUSSION}

Ross procedure in itself is a technically demanding procedure with greater cross-clamping time as compared to other aortic valve replacement techniques. In this series, two different techniques of Ross procedure were employed. These included free standing total root replacement and modified total root replacement using Dacron interposition graft to stabilise the autograft. The competency of autograft is enhanced by complete root replacement as it maintains the geometry of graft as well as remove all abnormal aortic root parts. Prior literature has indicated higher rates of aortic root dilatation and aortic regurgitation with free standing root replacement without autograft stabilisation. ${ }^{5}$ Although in this series, the outcome of both techniques inclusive of mortality, neo-aorta deterioration, and RVOT conduit failure requiring reoperation were similar. However, it is difficult to compare these techniques in a short case series. These results necessitate the need to assess the results of various Ross procedure practices in larger studies to provide evidence for optimal technique to be implemented in this population.

Another aspect to focus is the use of types of conduits for right ventricular outflow tract reconstruction. RVOT is considered to be the 'weak link' of Ross procedure contributing to majority of re-operations. The wellestablished transcatheter techniques enable the patients to have longer freedom from re-operation now. Use of Contegra, a gluteraldehyde-preserved heterologous bovine internal jugular vein with a trileaflet venous valve, provides the benefit of easy suturing without need of proximal or distal extension and large availability of various sizes ( 12 to 22 millimeters internal diameter). 8 Long term durability of bovine jugular vein graft is reported in a prior study with freedom from reintervention upto $90 \%$ at seven years. ${ }^{9}$ Another technique utilised was manually constructed composite valved conduit involving the use of PTFE membrane for constructing RVOT patch within bovine pericardial tube. The major benefit of PTFE membrane is its functionality for longer periods by evading tissue ingrowth leading to rates of freedom from re-operation ranging between $96 \%$ at one year, $89 \%$ at five years, and $82 \%$ at 10 years. ${ }^{10}$

\section{CONCLUSION}

The various techniques of Ross procedure utilising pulmonary autograft carry freedom from risks of anticoagulation, mortality, and RVOT conduit failure. All these benefits merit the evaluation of these technical varieties in larger studies assessing more practices with longer follow-up time duration to devise optimal strategy in younger adults.

\section{REFERENCES}

1. Legarra JJ, Concha M, Casares J, Merino C, Muñoz I, Alados P. Left ventricular remodeling after pulmonary autograft replacement of the aortic valve (Ross operation). J Heart Valve Dis 2001; 10:43-8.

2. Berdajs DA, Muradbegovic M, Haselbach D, Kofmehl R, Steurer J, Ferrari E, et al. Ross procedure: is the root replacement technique superior to the sub-coronary implantation technique? Long-term results. Eur J Cardiothorac Surg 2014; 46:944-51.

3. Ross DN. Replacement of aortic and mitral valves with a pulmonary autograft. Lancet 1967; 2:956-8.

4. Stelzer P, Jones DJ, Elkins RC. Aortic root replacement with pulmonary autograft. Circulation 1989; 80:III209-13.

5. Frigiola A, Ranucci M, Carlucci C, Giamberti A, Abella R, Di Donato $M$. The ross procedure in adults: long-term follow-up and echocardiographic changes leading to pulmonary autograft reoperation. Ann Thorac Surg 2008; 86:482-9.

6. Klena JW, Shweiki E, Mahaffey HW, Woods EL, Benoit CH, Gilbert CL. Annuloplasty and aortoplasty as modifications of the Ross procedure for the correction of geometric mismatch. $J$ Heart Valve Dis 2000; 9:195-9.

7. Juthier F, Banfi C, Vincentelli A, Ennezat PV, Le Tourneau T, Pinçon C, et al. Modified Ross operation with reinforcement of the pulmonary autograft: Six-year results. $J$ Thorac Cardiovasc Surg 2010; 139:1420-3.

8. Corno AF, Hurni M, Griffin H, Galal OM, Payot M, Sekarski N, et al. Bovine jugular vein as right ventricle-to-pulmonary artery valved conduit. J Heart Valve Dis 2002; 11:242-7.

9. Sierra J, Christenson JT, Lahlaidi NH, Beghetti M, Kalangos A. Right ventricular outflow tract reconstruction: what conduit to use? Homograft or Contegra? Ann Thorac Surg 2007; 84: 606-10.

10. Brown JW, Ruzmetov M, Vijay P, Rodefeld MD, Turrentine MW. Right ventricular outflow tract reconstruction with a polytetrafluoroethylenemonocusp valve: A twelve-year experience. $J$ Thorac Cardiovasc Surg 2007; 133:1336-43. 